\title{
KLASIFIKASI SISWA BERDASARKAN MATA PELAJARAN LINTAS MINAT MENGGUNAKAN METODE DECISION TREE C4.5
}

\author{
Suherman $^{1}$, Marlia Purnamasari ${ }^{2}$, Fitriani Dwi Hastuti ${ }^{3}$ \\ 1,2,3 Jurusan Teknik Informatika Fakultas Teknologi Informasi Universitas Serang Raya \\ Jln. Raya Cilegon Serang - Drangong Kota Serang \\ ${ }^{1}$ suherman.unsera@gmail.com \\ ${ }^{2}$ marlia.unsera@gmail.com \\ ${ }^{3}$ fitrianidwihastuti@gmail.com
}

\begin{abstract}
Abstrak - Kurikulum 2013 dirancang untuk memberikan kesempatan kepada siswa belajar berdasarkan minat siswa. Selain memilih mata pelajaran dalam suatu peminatan tertentu, siswa juga diberi kesempatan untuk mengambil mata pelajaran lintas minat. SMA Negeri 1 Anyer salah satu sekolah yang telah menerapkan program lintas minat. Dalam proses penentuan kelas lintas minat disekolah tersebut masih mengalami kendala yaitu tidak terspesifikasinya siswa yang memiliki minat pada mata pelajaran tertentu, dan pada proses pemilihan lintas minat ditentukan oleh pihak sekolah. Penelitian ini bertujuan untuk mengklasifikasi siswa berdasarkan minat dan bakat siswa pada mata pelajaran tertentu. Metode yang digunakan yaitu Decision Tree dan algoritma C4.5. Pada penelitian ini didapat nilai akurasi sebesar 82,82\%. Penelitian menghasilkan sebuah sistem penentuan kelas lintas Minat. Model klasifikasi ini dapat membantu siswa dalam menentukan lintas minat dan dapat digunakan sebagai alternatif referensi bagi guru BK untuk dapat mengelompokkan siswa berdasarkan minat dan bakat siswa.
\end{abstract}

Kata Kunci : Algoritma C4.5, Decision Tree, Klasfikasi, Lintas Minat

\section{Pendahuluan}

Kurikulum Tahun 2013 dirancang untuk memberikan kesempatan kepada siswa belajar berdasarkan minat mereka. Struktur kurikulum tahun 2013 menyediakan mata pelajaran wajib yang diikuti oleh seluruh peserta didik di satu satuan pendidikan pada setiap satuan dan jenjang pendidikan dan mata pelajaran pilihan yang diikuti oleh peserta didik sesuai dengan pilihan mereka.

Dalam Kurikulum 2013, selain memilih mata pelajaran dalam suatu peminatan tertentu, siswa juga diberi kesempatan untuk mengambil mata pelajaran antar kelompok peminatan atau yang disebut lintas minat. Lintas Minat adalah program kulikuler yang disediakan untuk mengakomodasi perluasan pilihan minat, bakat dan/atau kemampuan akademik siswa dengan orientasi penguasaan kelompok mata pelajaran keilmuan di luar pilihan minat. Hal ini memberi peluang kepada siswa untuk mempelajari mata pelajaran yang diminati namun tidak terdapat pada kelompok mata pelajaran peminatan.
Lintas minat adalah program untuk memperluas dan mengembangkan minat, bakat dan kemampuan peserta didik yang mereka miliki dengan memilih kelompok mata pelajaran, di luar kelompok program peminatannya [1]. Menurut Innike Marbitha Putri [2] Program ini bertujuan untuk memberikan kesempatan dan peluang kepada siswa untuk dapat memilih dan mempelajari mata pelajaran yang tidak ada pada program peminatan.

SMA Negeri 1 Anyer merupakan salah satu lembaga pendidikan menengah negeri di kabupaten Serang. Sesuai dengan keputusan pemerintah No. 81A Tahun 2013 tentang Implementasi Kurikulum 2013, maka SMA Negeri 1 Anyer sesuai dengan keputusan tersebut juga wajib menerapkan kurikulum 2013. Dalam proses penentuan mata pelajaran lintas minat pada sekolah tersebut masih mengalami kendala yaitu tidak terspesifikasinya siswa yang memiliki minat pada mata pelajaran tertentu dan pada proses pemilihan kelas lintas minat ditentukan oleh pihak sekolah. Jika kelas lintas minat tidak sesuai dengan minat dan kemampuan siswa, maka akan sangat berpengaruh pada proses belajar siswa kedepannya. 
Penelitian ini akan memberikan kemudahan bagi siswa untuk mengetahui kelas lintas minat yang sesuai dengan minat dan bakat, yaitu dengan pengembangan aplikasi menggunakan metode decision tree dan Algoritma C4.5, dengan memberikan pilihan - pilihan kriteria mata pelajaran lintas minat maka siswa akan memilih sesuai dengan minat dan bakat siswa tersebut.

Gorunescu mengemukakkan bahwa decision tree atau pohon keputusan adalah pohon yang digunakan sebagai prosedur penalaran untuk mendapatkan jawaban dari masalah yang dimasukkan. Kefleksibelan membuat metode ini atraktif, khususnya karena memberikan keuntungan berupa visualisasi saran (dalam bentuk decision tree) yang membuat prosedur prediksinya dapat diamati [3].

Penelitian ini akan membahas model data mining yang dapat memberikan solusi penyelesaian atas kendala siswa yang akan memilih mata pelajaran lintas minat dan pengembangan aplikasi ini berbasis web. Cara kerja aplikasi ini yaitu user memilih salah satu dari kriteria yang telah disediakan. Hasil penentuan mata pelajaran lintas minat didasarkan atas hasil perhitungan dengan metode klasifikasi decision tree dan menggunakan algoritma C4.5. Jika hasil dari perhitungan tersebut cenderung pada mata pelajaran pertama, maka siswa tersebut disarankan untuk masuk ke dalam kelas mata pelajaran pertama. Begitupun jika hasil perhitungannya cenderung pada mata pelajaran kedua atau ketiga maka siswa tersebut disarankan untuk masuk dalam kelas mata pelajaran kedua atau ketiga.

Pada penelitian ini menghasilkan sebuah aplikasi yang dikembangkan dengan bahasa pemrograman PHP sebagai Server Side Programming dan MySQL sebagai Database Server. Dalam perancangan sistemnya menggunakan UML (Unfied Modeling Language), yaitu sekumpulan konversi pemodelan yang digunakan untuk menentukan atau menggambarkan sebuah sistem software yang terkait dengan objek [4]. UML berarti memiliki sintaks dan sistematik. Ketika membuat model menggunakan konsep UML ada aturan-aturan yang harus diikuti. Bagaimana elemen pada model-model yang dibuat berhubungan satu dengan lainnya harus mengikuti standar yang ada. Seperti use case diagram, activity diagram, sequence diagram dan diagram class [5].

\section{Metodologi Penelitian}

Sumber data adalah segala sesuatu yang dapat memberikan informasi mengenai data. Berdasarkan sumbernya, data dibedakan menjadi dua yaitu data primer dan sekunder [6]. Pada penelitian ini sumber data yang digunakan oleh peneliti yaitu sumber data primer yang didapat melalui kuesioner pada siswa langsung.

Data mining adalah suatu istilah yang digunakan untuk menguraikan penemuan pengetahuan di dalam database. Data mining adalah proses yang menggunakan teknik statistik, matematika, kecerdasan buatan, dan machine learning untuk mengekstraksi dan mengidentifikasi informasi yang bermanfaat dan pengetahuan yang terkait dari berbagai database besar [7].

\subsection{Decision Tree}

Decision Tree atau pohon keputusan merupakan grafik diagram alir yang mewakili proses pengambilan keputusan, dimana grafik diagram alir tersebut menyerupai bentuk pohon. Pohon keputusan dapat digunakan seseorang untuk menentukan keputusan yang sulit dengan menyederhanakannya ke dalam pilihan yang lebih mudah. Setiap pohon keputusan memiliki simpul (node) dan cabang (branch) yang menghubungkan setiap simpul (nodes). Bagian simpul yang terletak di bagian bawah pohon keputusan disebut dengan klass keputusan (leaves) sedangkan simpul paling atas dari pohon keputusan disebut dengan root. Melalui root inilah dapat diketahui keseluruhan sample data training yang sudah terbagi ke dalam klas-klas keputusan tertentu. Setiap simpul pada pohon keputusan (kecuali leaves) disebut sebagai simpul keputusan. Simpul keputusan inilah yang memberikan informasi keputusan berdasarkan fitur tunggal berupa value yang merujuk pada salah satu leaves yang dimilikinya [8].

\subsection{Algoritma C4.5}

C4.5 diperkenalkan oleh Quinlan (1996) sebagai versi perbaikan dari ID3. Perbaikan yang membedakan algoritma C4.5 dari ID3 adalah dapat menangani fitur dengan tipe numerik, melakukan pemotongan (purning) decision tree, dan penurunan (deriving) rule set. Algoritma $\mathrm{C} 4.5$ juga menggunakan kriteria gain dalam menentukan fitur yang menjadi pemecah node pada pohon yang diinduksi [3].

Berikut langkah-langkah penyelesaian decision tree menggunakan algoritma C4.5 [8]:

1. Developing and understanding the application domain

Tujuan yang ingin dicapai dari proses ini yaitu klasifikasi siswa berdasarkan lintas minat.

2. Creating a target data set

Variabel (atribut) yang digunakan yaitu nama, nisn, jenis_kelamin, kelas, jawaban_a, jawaban_b, dan jawaban_c. Data point (sample) yang akan digunakan yaitu minat_asli.

3. Data celaning and preprocessing.

Pada tahap ini dilakukan proses penghapusan data yang tidak diharapkan keberadaannya (outliers), atribut yang dihilangkan yaitu: nisn, jenis_kelamin dan kelas.

4. Data reduction and projection

Dari tahapan data cleaning and preprocesing maka atribut yang digunakan yaitu jawaban_a, jawaban_b dan jawaban_c. Ketiga atribut tersebut merupakan kriteria numerik/kontinyu. Untuk meningkatkan tingkat akurasi metode klasifikasi, maka dilakukan proses diskritisasi menggunakan teknik unsupervised discretization.

Diantara metode unsupervised Discretization, terdapat beberapa metode yang sederhana. Seperti (equal-width Interval Discretization dan equal- frequency Interval 
Discretization) dan yang lebih canggih, berdasarkan analisis clustering, seperti k-means discretization. Rentang kontinu dibagi menjadi sub rentang oleh lebar yang ditentukan pengguna atau Frekuensi [9].

Teknik unsupervised discretization pada kriteria yang bernilai numerik/kontinyu, tujuannya adalah untuk mentransformasikan kriteria yang bernilai numerik/kontinyu menjadi kriteria kategorikal seperti berikut :

$$
\begin{gathered}
\text { Interval }=\frac{V \max -V \min }{k} \\
\text { Interval }=\frac{30-0}{3}=10
\end{gathered}
$$

Kemudian menentukan batas-batas sebagai berikut :

Boundaries $=V \min +(i *$ interval $)$

Boundaries $(1)=0+(1 * 10)=10$

Boundaries $(2)=0+(2 * 10)=20$

Boundaries $(3)=0+(3 * 10)=30$

Maka diperoleh nilai kategorikal atribut sebagai berikut :

TABEL I. NILAI KATEGORIKAL

\begin{tabular}{|c|c|c|}
\hline Jawaban_A & Jawaban_B & Jawaban_C \\
\hline$\leq 10$ & $\leq 10$ & $\leq 10$ \\
\hline$>10$ & $>10$ & $>10$ \\
\hline$\leq 20$ & $\leq 20$ & $\leq 20$ \\
\hline$>20$ & $>20$ & $>20$ \\
\hline$\leq 30$ & $\leq 30$ & $\leq 30$ \\
\hline$>30$ & $>30$ & $>30$ \\
\hline
\end{tabular}

\section{Choosing the data mining task}

Metode data mining yang digunakan yaitu pohon klasifikasi, karena sesuai dengan tujuan yang ingin dicapai.

6. Choosing the data mining algorithm

Algoritma yang digunakan yaitu algoritma C4.5.

7. Data mining

TABEL II. DATA TRAINING PERTAMA

\begin{tabular}{|c|c|c|c|c|c|}
\hline 20 & Arya Dwi S & 17 & 6 & 7 & Biologi \\
\hline 21 & Asnah & 25 & 3 & 2 & Biologi \\
\hline 22 & Bagas Parmono & 12 & 11 & 7 & Biologi \\
\hline 23 & Cindy Ayu K S & 8 & 19 & 3 & Kimia \\
\hline 24 & Cinta Azahra & 25 & 2 & 3 & Biologi \\
\hline 25 & Danu S & 21 & 6 & 3 & Biologi \\
\hline 26 & Desti Vinita A & 12 & 7 & 11 & Biologi \\
\hline 27 & Dewi Ratnasari & 14 & 10 & 6 & Biologi \\
\hline 28 & Dhayanu P & 23 & 2 & 5 & Biologi \\
\hline 29 & Dhea Liana P & 17 & 10 & 3 & Biologi \\
\hline 30 & Diki Rosadi & 5 & 12 & 13 & Fisika \\
\hline 31 & Dimas P. A & 10 & 10 & 10 & Fisika \\
\hline 32 & Dini Wahyuni & 17 & 10 & 3 & Biologi \\
\hline 33 & Dita Imelda & 13 & 12 & 5 & Biologi \\
\hline 34 & Endar Rifaldi & 12 & 11 & 7 & Biologi \\
\hline 35 & Eri Irawan & 14 & 12 & 4 & Biologi \\
\hline 36 & Erlinda Putri & 14 & 7 & 9 & Biologi \\
\hline 37 & Fadila R & 7 & 19 & 4 & Kimia \\
\hline 38 & Faizal Bagus Z & 9 & 12 & 9 & Kimia \\
\hline 39 & Farid Puji F R & 6 & 9 & 15 & Fisika \\
\hline 40 & Fariz Ilham R & 9 & 12 & 9 & Kimia \\
\hline 41 & Fasya Saskia & 11 & 12 & 7 & Kimia \\
\hline 42 & Fauziah & 22 & 6 & 2 & Biologi \\
\hline 43 & Fironica N. A & 16 & 9 & 5 & Biologi \\
\hline 44 & Hafidz Ainur R & 14 & 8 & 8 & Biologi \\
\hline 45 & Hani Hunarti & 11 & 13 & 6 & Kimia \\
\hline 46 & Ihya Ulum M & 7 & 6 & 17 & Fisika \\
\hline 47 & Ike Mutiara A & 19 & 8 & 3 & Biologi \\
\hline 48 & Indra Maulana & 14 & 6 & 10 & Biologi \\
\hline 49 & Intan Wulandari & 15 & 7 & 8 & Biologi \\
\hline 50 & Jahratul H & 26 & 3 & 1 & Biologi \\
\hline 51 & Jimi Fauzan & 8 & 9 & 12 & Fisika \\
\hline 52 & Juhiar & 9 & 12 & 9 & Kimia \\
\hline 53 & Julita & 18 & 7 & 4 & Biologi \\
\hline 54 & Kayla Rayane P & 14 & 11 & 5 & Biologi \\
\hline 55 & Kholis Femas F & 13 & 14 & 3 & Kimia \\
\hline 56 & Lis Nurmala & 12 & 13 & 5 & Kimia \\
\hline 57 & Lisna $\mathrm{N}$ & 12 & 15 & 3 & Kimia \\
\hline 58 & M Fikri Rivaldi & 8 & 10 & 12 & Fisika \\
\hline 59 & M Nascar R & 16 & 8 & 6 & Biologi \\
\hline 60 & M Rojid & 7 & 17 & 8 & Kimia \\
\hline 61 & Marcella Devita & 12 & 13 & 5 & Kimia \\
\hline 62 & Mario Maulana & 30 & 0 & 0 & Biologi \\
\hline 63 & Marni & 12 & 13 & 5 & Kimia \\
\hline 64 & Masani & 4 & 23 & 3 & Kimia \\
\hline 65 & Maudy Al & 17 & 10 & 3 & Biologi \\
\hline 66 & Maulinda P N & 16 & 6 & 8 & Biologi \\
\hline 67 & Mohamad Dafa & 10 & 14 & 6 & Kimia \\
\hline 68 & Muhammad C S & 11 & 6 & 13 & Fisika \\
\hline 69 & Muhammad Z & 12 & 10 & 8 & Biologi \\
\hline 70 & Mulyana Sari & 30 & 0 & 0 & Biologi \\
\hline 71 & Nabila Novianti & 16 & 9 & 5 & Biologi \\
\hline 72 & Nafis Baldan & 16 & 8 & 6 & Biologi \\
\hline 73 & Nasywa Dany A & 12 & 10 & 8 & Biologi \\
\hline 74 & Nessa Eka Putri & 13 & 7 & 10 & Biologi \\
\hline 75 & Nilam Cahya & 16 & 10 & 4 & Biologi \\
\hline 76 & Nisa Zahrani & 2 & 3 & 25 & Fisika \\
\hline 77 & Nur Ayu P & 12 & 13 & 5 & Kimia \\
\hline 78 & Nurcahyani & 11 & 7 & 12 & Fisika \\
\hline 79 & Nurjanah & 8 & 20 & 2 & Kimia \\
\hline 80 & Nurul Sofiana & 24 & 5 & 1 & Biologi \\
\hline 81 & Raditya Dwi P & 10 & 7 & 13 & Fisika \\
\hline 82 & Raisha Azzahra & 15 & 8 & 7 & Biologi \\
\hline 83 & Rendi Setiawan & 18 & 5 & 7 & Biologi \\
\hline 84 & Rikaz Ayatullah & 12 & 11 & 7 & Biologi \\
\hline
\end{tabular}

\begin{tabular}{|c|l|c|c|c|c|}
\hline No & \multicolumn{1}{|c|}{ Nama } & A & B & C & $\begin{array}{c}\text { Minat } \\
\text { Asli }\end{array}$ \\
\hline 1 & Abdul Malik R & 18 & 9 & 3 & Biologi \\
\hline 2 & Achmad Daviq & 8 & 10 & 12 & Fisika \\
\hline 3 & Adnan Setiawan & 11 & 11 & 8 & Biologi \\
\hline 4 & Adrian Maulana & 13 & 9 & 8 & Biologi \\
\hline 5 & Agus Irawan & 5 & 10 & 15 & Fisika \\
\hline 6 & Ahmad As'adi Z & 5 & 13 & 12 & Kimia \\
\hline 7 & Ahmad Fauzi S & 9 & 9 & 12 & Fisika \\
\hline 8 & Ahmad Nugi & 12 & 10 & 8 & Biologi \\
\hline 9 & Aldi Yusufandi & 11 & 4 & 15 & Fisika \\
\hline 10 & Alif Riswanda & 14 & 7 & 9 & Biologi \\
\hline 11 & Alifia Najwa A & 14 & 9 & 7 & Biologi \\
\hline 12 & Alvia Septiani & 17 & 12 & 1 & Biologi \\
\hline 13 & Alvin Maulana & 19 & 6 & 5 & Biologi \\
\hline 14 & Ananda Widya & 11 & 9 & 10 & Biologi \\
\hline 15 & Anes Awaliyah & 12 & 15 & 3 & Kimia \\
\hline 16 & Anisa S & 15 & 9 & 6 & Biologi \\
\hline 17 & Arif F & 9 & 14 & 7 & Kimia \\
\hline 18 & Arya Darma J.S & 13 & 12 & 5 & Biologi \\
\hline 19 & Arya Difa & 12 & 10 & 8 & Biologi \\
\hline
\end{tabular}




\begin{tabular}{|c|l|c|c|c|c|}
\hline 85 & Riska Agustina & 10 & 12 & 8 & Kimia \\
\hline 86 & Riska Utami & 14 & 10 & 6 & Biologi \\
\hline 87 & Rizka Alifia M & 16 & 8 & 6 & Biologi \\
\hline 88 & Salwa Saidah A & 22 & 5 & 3 & Biologi \\
\hline 89 & Serlina & 4 & 15 & 11 & Kimia \\
\hline 90 & Shabilla Siti R & 24 & 6 & 0 & Biologi \\
\hline 91 & Siti Nurdiana A & 14 & 13 & 3 & Biologi \\
\hline 92 & Siti Nurma A & 6 & 7 & 17 & Fisika \\
\hline 93 & Siti Salma S & 19 & 9 & 2 & Biologi \\
\hline 94 & Siti Sya'riatul M & 5 & 10 & 15 & Fisika \\
\hline 95 & Sri Mulliyati & 20 & 9 & 1 & Biologi \\
\hline 96 & Syifa Aulia R G & 12 & 11 & 7 & Biologi \\
\hline 97 & Trisda Cahya R & 20 & 6 & 4 & Biologi \\
\hline 98 & Valentina & 9 & 9 & 12 & Fisika \\
\hline 99 & Wilda Meilani & 19 & 8 & 3 & Biologi \\
\hline 100 & Windi W & 16 & 12 & 2 & Biologi \\
\hline 101 & Yoshavath A P & 11 & 11 & 8 & Kimia \\
\hline 102 & Yunita Fitria D & 27 & 2 & 1 & Biologi \\
\hline 103 & Zahra Rizki A & 11 & 11 & 8 & Biologi \\
\hline
\end{tabular}

Sumber : SMA Negeri 1 Anyer, 2019

\section{Penyelesaian}

a. Tentukan jumlah himpunan Biologi, Kimia dan Fisika Pada kasus ini jumlah himpunan biologi yakni sebanyak 63, kimia sebanyak 23 dan fisika sebanyak 17.

b. Hitung nilai entropy sample training total

$$
\text { Entropy }(S)=\sum_{i=1}^{n}-p i \times \log _{2} p i
$$

Entropy $($ total $)=-\frac{63}{103} \log _{2}\left(\frac{63}{103}\right)-\frac{23}{103} \log _{2}\left(\frac{23}{103}\right)-\frac{17}{103} \log _{2}\left(\frac{17}{103}\right)=1,346$

c. Hitung nilai entropy setiap atribut terhadap entropy total Perhitungan Entropy dilakukan terhadap klass atribut Decision.

1) Menghitung nilai entropy jawaban a $\leq 10$ dan $>10$

Atribut jawaban a $\leq 10$ dan $>10$ memiliki 2 buah jenis value yaitu $\leq 10$ sebanyak 27 buah dan $>10$ sebanyak 76 buah. Dengan demikian perhitungan nilai entropy untuk setiap value atribut diperoleh sebagai berikut :

$$
\begin{aligned}
& \text { Entropy }\left(S_{i} \text { jawaban } a \leq 10\right)=-\frac{13}{27} \log _{2}\left(\frac{13}{27}\right)-\frac{14}{27} \log _{2}\left(\frac{14}{27}\right)=0,999 \\
& \text { Entropy }\left(S_{\text {, jawaban }}>10\right)=-\frac{63}{76} \log _{2}\left(\frac{63}{76}\right)-\frac{10}{76} \log _{2}\left(\frac{10}{76}\right)-\frac{3}{76} \log _{2}\left(\frac{3}{76}\right)=0,498
\end{aligned}
$$

2) Menghitung nilai entropy jawaban_a $\leq 20$ dan $>20$

Atribut jawaban_a $\leq 20$ dan $>20$ memiliki 2 buah jenis value yaitu $\leq 20$ sebanyak 91 buah dan $>20$ sebanyak 12 . Dengan demikian perhitungan nilai entropy untuk setiap value atribut diperoleh sebagai berikut :

Entropy $\left(S\right.$, jawaban $\left._{a} \leq 20\right)=-\frac{51}{91} \log _{2}\left(\frac{51}{91}\right)-\frac{23}{91} \log _{2}\left(\frac{23}{91}\right)-\frac{17}{91} \log _{2}\left(\frac{17}{91}\right)=1,422$

Entropy $\left(S\right.$, jawaban $\left._{a} \leq 20\right)=-\frac{12}{12} \log _{2}\left(\frac{12}{12}\right)=0$

3) Menghitung nilai entropy jawaban_a $\leq 30$ dan $>30$

Atribut jawaban a $\leq 30$ dan $>30$ memiliki 2 buah jenis value yaitu $\leq 30$ sebanyak 103 buah dan $>30$ sebanyak 0 buah. Dengan demikian perhitungan nilai entropy untuk setiap value atribut diperoleh sebagai berikut :

Entropy $\left(S\right.$, jawaban $\left._{a} \leq 30\right)=-\frac{63}{103} \log _{2}\left(\frac{63}{103}\right)-\frac{23}{103} \log _{2}\left(\frac{23}{103}\right)-\frac{17}{103} \log _{2}\left(\frac{17}{103}\right)=1,346$

$\operatorname{Entropy}\left(S\right.$, jawaban $\left._{a}>30\right)=-\frac{0}{0} \log _{2}\left(\frac{0}{0}\right)=0$

4) Menghitung nilai entropy jawaban_b $\leq 10$ dan $>10$

Atribut jawaban_b $\leq 10$ dan $>10$ memiliki 2 buah jenis value yaitu $\leq 10$ sebanyak 66 buah dan $>10$ sebanyak 37 buah. Dengan demikian perhitungan nilai entropy untuk setiap value atribut diperoleh sebagai berikut :

Entropy $\left(S_{,}\right.$jawaban $\left.b \leq 10\right)=-\frac{50}{66} \log _{2}\left(\frac{50}{66}\right)-\frac{16}{66} \log _{2}\left(\frac{16}{66}\right)=0,799$

Entropy $\left(S_{i j a w a b a n_{b}}>10\right)=-\frac{13}{37} \log _{2}\left(\frac{13}{37}\right)-\frac{23}{37} \log _{2}\left(\frac{23}{37}\right)-\frac{1}{37} \log _{2}\left(\frac{1}{37}\right)=1,097$

5) Menghitung nilai entropy jawaban $b \leq 20$ dan $>20$

Atribut jawaban_b $\leq 20$ dan $>20$ memiliki 2 buah jenis value yaitu $\leq 20$ sebanyak 102 buah dan $>20$ sebanyak 1 buah. Dengan demikian perhitungan nilai entropy untuk setiap value atribut diperoleh sebagai berikut :

Entropy $\left(S_{x}\right.$ jawaban $\left.n_{b} \leq 20\right)=-\frac{62}{66} \log _{2}\left(\frac{62}{66}\right)-\frac{22}{66} \log _{2}\left(\frac{22}{66}\right)-\frac{17}{66} \log _{2}\left(\frac{17}{66}\right)=1,337$

Entropy $\left(S_{i}\right.$ jawaban $\left._{b}>20\right)=-\frac{1}{1} \log _{2}\left(\frac{1}{1}\right)=0$

6) Menghitung nilai entropy jawaban_b $\leq 30$ dan $>30$

Atribut jawaban $b \leq 30$ dan $>30$ memiliki 2 buah jenis value yaitu $\leq 30$ sebanyak 103 buah dan $>30$ sebanyak 0 buah. Dengan demikian perhitungan nilai entropy untuk setiap value atribut diperoleh sebagai berikut :

Entropy $\left(S\right.$, jawaban $\left._{b} \leq 30\right)=-\frac{63}{103} \log _{2}\left(\frac{63}{103}\right)-\frac{23}{103} \log _{2}\left(\frac{23}{103}\right)-\frac{17}{103} \log _{2}\left(\frac{17}{103}\right)=1,346$

$\operatorname{Entropy}\left(S\right.$, jawaban $\left._{b}>30\right)=-\frac{0}{0} \log _{2}\left(\frac{0}{0}\right)=0$

7) Menghitung nilai entropy jawaban_c $\leq 10$ dan $>10$

Atribut jawaban $\mathrm{c} \leq 10$ dan $>10$ memiliki 2 buah jenis value yaitu $\leq 10$ sebanyak 83 buah dan $>10$ sebanyak 20 buah. Dengan demikian perhitungan nilai entropy untuk setiap value atribut diperoleh sebagai berikut :

Entropy $\left(S_{i}\right.$ jawaban $\left.0 \leq 10\right)=-\frac{62}{83} \log _{2}\left(\frac{62}{83}\right)-\frac{21}{83} \log _{2}\left(\frac{21}{83}\right)=0,819$

Entropy $\left(S_{x}\right.$ jawaban $\left._{c}>10\right)=-\frac{1}{20} \log _{2}\left(\frac{1}{20}\right)-\frac{2}{20} \log _{2}\left(\frac{2}{20}\right)-\frac{17}{20} \log _{2}\left(\frac{17}{20}\right)=0,74 \mathrm{\varepsilon}$

8) Menghitung nilai entropy jawaban_c $\leq 20$ dan $>20$

Atribut jawaban_c $\leq 20$ dan $>20$ memiliki 2 buah jenis value yaitu $\leq 20$ sebanyak 102 buah dan $>20$ sebanyak 1 buah. Dengan demikian perhitungan nilai entropy untuk setiap value atribut diperoleh sebagai berikut : 
Entropy $\left(S_{\text {j jawaban }} \leq 20\right)=-\frac{63}{102} \log _{2}\left(\frac{63}{102}\right)-\frac{23}{102} \log _{2}\left(\frac{23}{102}\right)-\frac{17}{102} \log _{2}\left(\frac{17}{102}\right)=1,333$

Entropy $\left(S_{i j a w a b a n_{e}}>20\right)=-\frac{1}{1} \log _{2}\left(\frac{1}{1}\right)=0$

9) Menghitung nilai entropy jawaban_c $\leq 30$ dan $>30$

Atribut jawaban_c $\leq 30$ dan $>30$ memiliki 2 buah jenis value yaitu $\leq 30$ sebanyak 103 buah dan $>30$ sebanyak 0 buah. Dengan demikian perhitungan nilai entropy untuk setiap value atribut diperoleh sebagai berikut :

Entropy $\left(S_{s}\right.$ jawaban $\left._{e} \leq 30\right)=-\frac{63}{103} \log _{2}\left(\frac{63}{103}\right)-\frac{23}{103} \log _{2}\left(\frac{23}{103}\right)-\frac{17}{103} \log _{2}\left(\frac{17}{103}\right)=1,346$

Entropy $\left(S_{i}\right.$ jawaban $\left._{c}>30\right)=-\frac{0}{0} \log _{2}\left(\frac{0}{0}\right)=0$

d. Menghitung nilai information gain tiap atribut Information Gain $\left(S, F_{j}\right)=\operatorname{Entropy}(S)-\sum_{V_{i} \in V_{F_{j}}} \frac{\left|S_{V_{i}}\right|}{|S|} \cdot \operatorname{Entropy}\left(S_{V_{i}}\right)$ Information Gain $\left(\right.$ Jawaban $_{a} \leq 10$ dan $\left.>10\right)=1,346-\frac{27}{103} \cdot 0,999-\frac{76}{103} \cdot 0,793=0,498$ Information Gain $\left(\right.$ Jawaban $_{a} \leq 20$ dan $\left.>20\right)=1,346-\frac{91}{103} \cdot 1,422-\frac{91}{103} \cdot 0=0,090$ Information Gain ( Jawaban $_{a} \leq 30$ dan $\left.>30\right)=1,346-\frac{103}{103} \cdot 1,346=0$ Information Gain $\left(\right.$ Jawaban $_{b} \leq 10$ dan $\left.>10\right)=1,346-\frac{66}{103} \cdot 0,799-\frac{37}{103} \cdot 1,097=0,440$ Information Gain $\left(\right.$ Jawaban $_{b} \leq 20$ dan $\left.>20\right)=1,346-\frac{102}{103} \cdot 1,337-\frac{1}{103} \cdot 0=0,021$ Information Gain $\left(\right.$ Jawaban $_{b} \leq 30$ dan $\left.>30\right)=1,346-\frac{103}{103} \cdot 1,346=0$ Information Gain $\left(\right.$ Jawaban $_{c} \leq 10$ dan $\left.>10\right)=1,346-\frac{83}{103} \cdot 0,816-\frac{20}{103} \cdot 0,748=0,543$ Information Gain $\left(\operatorname{Jawaban}_{c} \leq 20\right.$ dan 20) $=1,346-\frac{102}{103} \cdot 1,333-\frac{1}{103} \cdot 0=0,026$ Information Gain $\left(\right.$ Jawaban $_{c} \leq 30$ dan $\left.>30\right)=1,346-\frac{103}{103} \cdot 1,346=0$

e. Menentukan root tree

Informasi gain masing-masing atribut hasil perhitungan pertama seperti di bawah ini : TABEL III. INFORMATION GAIN PERTAMA

\begin{tabular}{|c|c|}
\hline Atribut & Information Gain \\
\hline Jawaban_a $\leq 10$ dan $>10$ & 0,498 \\
\hline Jawaban_a $\leq 20$ dan $>20$ & 0,090 \\
\hline Jawaban_a $\leq 30$ dan $>30$ & 0 \\
\hline Jawaban_b $\leq 10$ dan $>10$ & 0,440 \\
\hline Jawaban_b $\leq 20$ dan $>20$ & 0,021 \\
\hline Jawaban_b $\leq 30$ dan $>30$ & 0 \\
\hline Jawaban_c $\leq 10$ dan $>10$ & 0,543 \\
\hline Jawaban_c $\leq 20$ dan $>20$ & 0,026 \\
\hline Jawaban_c $\leq 30$ dan $>30$ & 0 \\
\hline
\end{tabular}

Berdasarkan perhitungan informasi gain, dapat dilihat bahwa nilai gain tertinggi dimiliki oleh atribut jawaban_c $\leq 10$ dan $>10$, sehingga dengan demikian jawaban_c dijadikan sebagai root dari pohon keputusan yang akan dibentuk.

Sedangkan simpul keputusan dilihat berdasarkan value atribut dari jawaban_c, yakni jika value atribut memiliki class target berbeda, maka dilakukan perhitungan nilai gain informasi kembali terhadap atribut tertentu yang merujuk pada value atribut yang menjadi root pohon keputusan.

Berikut merupakan ilustrasi terbentuknya root pohon keputusan dengan simpul keputusan awal menurut value atribut yang dimilikinya.

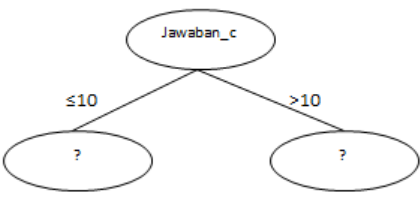

Gambar 1. Root Pohon Keputusan Kesatu

f. Setelah atribut jawaban_c $\leq 10$ dan $>10$ menjadi atribut root, maka data training awal kemudian menyusut setelah terjadi split data training. Berikut informasi gain masingmasing atribut hasil perhitungan kedua seperti di bawah ini :

TABEL IV. INFORMATION GAIN KEDUA

\begin{tabular}{|c|c|}
\hline Atribut & Information Gain \\
\hline Jawaban_a $\leq 10$ dan $>10$ & 0,312 \\
\hline Jawaban_a $\leq 20$ dan $>20$ & 0,189 \\
\hline Jawaban_a $\leq 30$ dan $>30$ & 0 \\
\hline Jawaban_b $\leq 10$ dan $>10$ & 0,423 \\
\hline Jawaban_b $\leq 20$ dan $>20$ & 0,024 \\
\hline Jawaban_b $\leq 30$ dan $>30$ & 0 \\
\hline
\end{tabular}

Berdasarkan perhitungan informasi gain, dapat dilihat bahwa nilai gain tertinggi dimiliki oleh atribut jawaban_b $\leq 10$ dan $>10$, sehingga dengan demikian jawaban $b \leq 10$ dan $>10$ dijadikan sebagai root dari pohon keputusan yang akan dibentuk.

Sedangkan simpul keputusan dilihat berdasarkan value atribut dari jawaban_b $\leq 10$ dan $>10$, yakni jika value atribut memiliki class target berbeda, maka dilakukan perhitungan nilai gain informasi kembali terhadap atribut tertentu yang merujuk pada value atribut yang menjadi root pohon keputusan.

Berikut merupakan ilustrasi terbentuknya root pohon keputusan dengan simpul keputusan awal menurut value atribut yang dimilikinya.

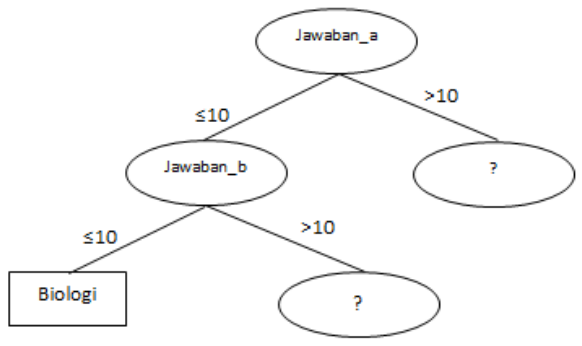


Gambar 2. Leaf Pohon Keputusan Kedua

g. Setelah atribut jawaban_b $\leq 10$ menjadi atribut root, maka data training awal kemudian menyusut setelah terjadi split data training. Selanjutnya menentukan leaf node untuk jawaban_b >10, Berikut informasi gain masing-masing atribut hasil perhitungan ketiga seperti di bawah ini :

TABEL V. INFORMATION GAIN KETIGA

\begin{tabular}{|c|c|}
\hline Atribut & Information Gain \\
\hline Jawaban_a $\leq 10$ dan $>10$ & 0,292 \\
\hline Jawaban_a $\leq 20$ dan $>20$ & 0 \\
\hline Jawaban_a $\leq 30$ dan $>30$ & 0 \\
\hline
\end{tabular}

Berdasarkan perhitungan informasi gain, dapat dilihat bahwa nilai gain tertinggi dimiliki oleh atribut jawaban_a $\leq 10$ dan $>10$, sehingga dengan demikian jawaban_a $\leq 10$ dan $>10$ dijadikan sebagai root dari pohon keputusan yang akan dibentuk. Sedangkan simpul keputusan dilihat berdasarkan value atribut dari jawaban_a $\leq 10$ dan $>10$, yakni jika value atribut memiliki class target berbeda, maka dilakukan perhitungan nilai gain informasi kembali terhadap atribut tertentu yang merujuk pada value atribut yang menjadi root pohon keputusan.

Berikut merupakan ilustrasi terbentuknya root pohon keputusan dengan simpul keputusan awal menurut value atribut yang dimilikinya

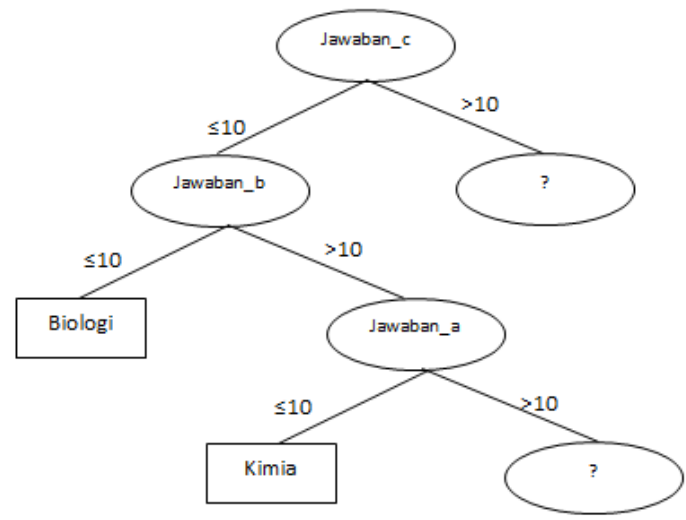

Gambar 3. Leaf Pohon Keputusan Ketiga

h. Setelah atribut jawaban_a $\leq 10$ menjadi atribut root, maka data training awal kemudian menyusut setelah terjadi split data training. Berikut informasi gain masing-masing atribut hasil perhitungan keempat seperti di bawah ini :

TABEL VI. INFORMATION GAIN KEEMPAT

\begin{tabular}{|c|c|}
\hline Atribut & Information Gain \\
\hline Jawaban_a $\leq 10$ dan $>10$ & 0 \\
\hline Jawaban_a $\leq 20$ dan $>20$ & 0 \\
\hline Jawaban_a $\leq 30$ dan $>30$ & 0 \\
\hline
\end{tabular}

Berdasarkan perhitungan informasi gain, dapat dilihat bahwa semua nilai gain atribut bernilai 0 sehingga perhitungan terhenti dan menghasilkan suatu keputusan.
Berikut merupakan ilustrasi terbentuknya root pohon keputusan dengan simpul keputusan awal menurut value atribut yang dimilikinya.

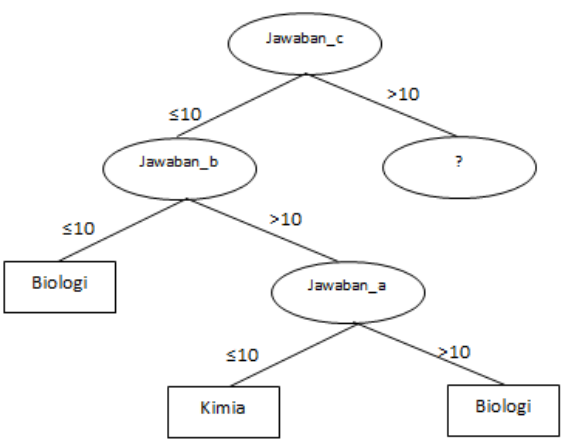

Gambar 4. Leaf Pohon Keputusan Keempat

i. Setelah pada langkah sebelumnya dilakukan penentuan atribut root dan terpilih jawaban_b menjadi leaf node, maka data training awal kemudian menyusut setelah terjadi split data training. Berikut informasi gain masingmasing atribut hasil perhitungan kelima seperti di bawah ini :

TABEL VII. INFORMATION GAIN KELIMA

\begin{tabular}{|c|c|}
\hline Atribut & Information Gain \\
\hline Jawaban_a $\leq 10$ dan $>10$ & 0,138 \\
\hline Jawaban_a $\leq 20$ dan $>20$ & 0 \\
\hline Jawaban_a $\leq 30$ dan $>30$ & 0 \\
\hline Jawaban_b $\leq 10$ dan $>10$ & 0,335 \\
\hline Jawaban_b $\leq 20$ dan $>20$ & 0 \\
\hline Jawaban_b $\leq 30$ dan $>30$ & 0 \\
\hline
\end{tabular}

Berdasarkan perhitungan informasi gain, dapat dilihat bahwa nilai gain tertinggi dimiliki oleh atribut jawaban_b $\leq 10$ dan $>10$, sehingga dengan demikian jawaban $b \leq 10$ dan $>10$ dijadikan sebagai root dari pohon keputusan yang akan dibentuk.

Sedangkan simpul keputusan dilihat berdasarkan value atribut dari jawaban $b \leq 10$ dan $>10$, yakni jika value atribut memiliki class target berbeda, maka dilakukan perhitungan nilai gain informasi kembali terhadap atribut tertentu yang merujuk pada value atribut yang menjadi root pohon keputusan.

Berikut merupakan ilustrasi terbentuknya root pohon keputusan dengan simpul keputusan awal menurut value atribut yang dimilikinya. 


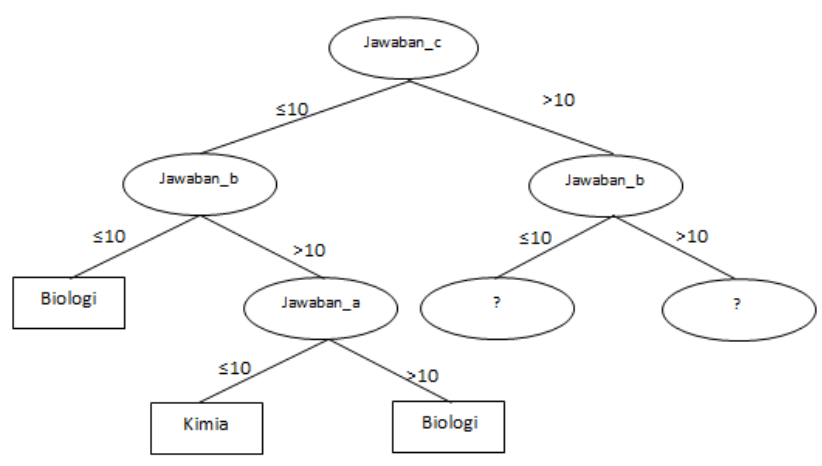

Gambar 5. Leaf Pohon Keputusan Kelima

j. Setelah atribut jawaban_b $>10$ menjadi atribut root, maka data training awal kemudian menyusut setelah terjadi split data training. Berikut informasi gain masing-masing atribut hasil perhitungan keenam seperti di bawah ini :

TABEL VII. INFORMATION GAIN KEENAM

\begin{tabular}{|c|c|}
\hline Atribut & Information Gain \\
\hline Jawaban_a $\leq 10$ dan $>10$ & 0,132 \\
\hline Jawaban_a $\leq 20$ dan $>20$ & 0 \\
\hline Jawaban_a $\leq 30$ dan $>30$ & 0 \\
\hline
\end{tabular}

Berdasarkan perhitungan informasi gain, dapat dilihat bahwa nilai gain tertinggi dimiliki oleh atribut jawaban_a $\leq 10$ dan $>10$, sehingga dengan demikian jawaban_a $\leq 10$ dan $>10$ dijadikan sebagai root dari pohon keputusan yang akan dibentuk.

Sedangkan simpul keputusan dilihat berdasarkan value atribut dari jawaban_a $\leq 10$ dan $>10$, yakni jika value atribut memiliki class target berbeda, maka dilakukan perhitungan nilai gain informasi kembali terhadap atribut tertentu yang merujuk pada value atribut yang menjadi root pohon keputusan.

Berikut merupakan ilustrasi terbentuknya root pohon keputusan dengan simpul keputusan awal menurut value atribut yang dimilikinya.

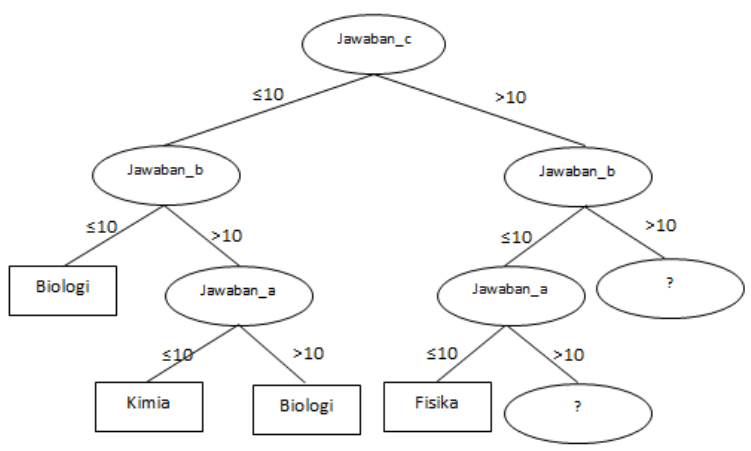

Gambar 6. Leaf Pohon Keputusan Keenam

k. Setelah atribut jawaban_a $>10$ menjadi atribut root, maka data training awal kemudian menyusut setelah terjadi split data training. Berikut informasi gain masing-masing atribut hasil perhitungan ketujuh seperti di bawah ini :

TABEL IX. INFORMATION GAIN KETUJUH

\begin{tabular}{|c|c|}
\hline Atribut & Information Gain \\
\hline Jawaban_a $\leq 10$ dan $>10$ & 0 \\
\hline Jawaban_a $\leq 20$ dan $>20$ & 0 \\
\hline Jawaban_a $\leq 30$ dan $>30$ & 0 \\
\hline
\end{tabular}

Berdasarkan perhitungan informasi gain, dapat dilihat bahwa semua nilai gain atribut bernilai 0 sehingga perhitungan terhenti dan menghasilkan suatu keputusan.

Berikut merupakan ilustrasi terbentuknya root pohon keputusan dengan simpul keputusan awal menurut value atribut yang dimilikinya.

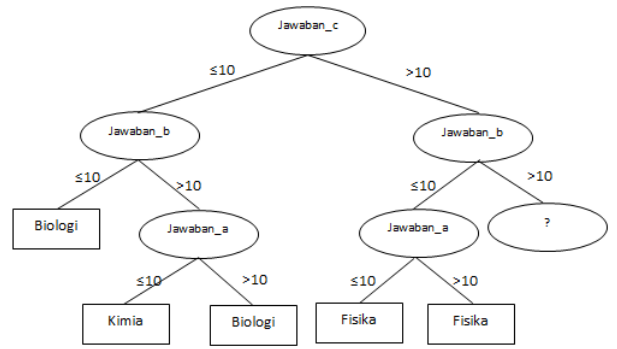

Gambar 7. Leaf Pohon Keputusan Ketujuh

1. Setelah pada langkah sebelumnya dilakukan penentuan atribut root dan terpilih jawaban_a menjadi leaf node, maka data training awal kemudian menyusut setelah terjadi split data training. Berikut informasi gain masingmasing atribut hasil perhitungan kedelapan seperti di bawah ini :

TABEL X. INFORMATION GAIN KEDELAPAN

\begin{tabular}{|c|c|}
\hline Atribut & Information Gain \\
\hline Jawaban_a $\leq 10$ dan $>10$ & 0 \\
\hline Jawaban_a $\leq 20$ dan $>20$ & 0 \\
\hline Jawaban_a $\leq 30$ dan $>30$ & 0 \\
\hline
\end{tabular}

Berdasarkan perhitungan informasi gain, dapat dilihat bahwa semua nilai gain atribut bernilai 0 sehingga perhitungan terhenti dan menghasilkan suatu keputusan. Berikut merupakan ilustrasi terbentuknya root pohon keputusan dengan simpul keputusan awal menurut value atribut yang dimilikinya.

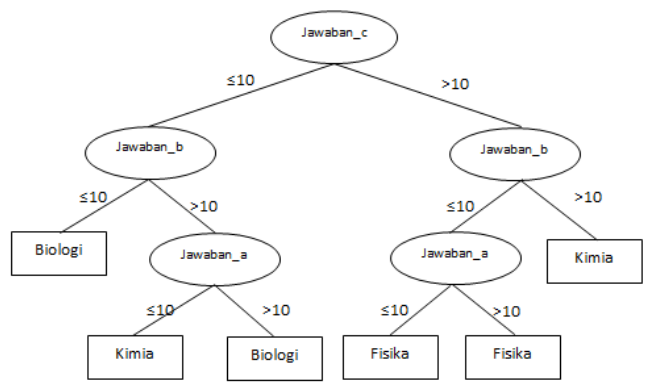

Gambar 8. Leaf Pohon Keputusan Kedelapan 
Berdasarkan pohon keputusan diatas maka diperoleh aturan rule sebagai berikut :

1) IF jawaban_c $\leq 10$ AND jawaban_b $\leq 10$ THEN Biologi

2) IF jawaban_c $\leq 10$ AND jawaban_b $>10$ AND jawaban_a $\leq 10$ THEN Kimia

3) IF jawaban_c $\leq 10$ AND jawaban_b $>10$ AND jawaban_a > 10 THEN Biologi

4) IF jawaban_c $>10$ AND jawaban_b $\leq 10$ AND jawaban_a $\leq 10$ THEN Fisika

5) IF jawaban_c $>10$ AND jawaban_b $\leq 10$ AND jawaban_a $>10$ THEN Fisika

6) IF jawaban_c > AND jawaban_b > 10 THEN Kimia

Setelah mendapatkan aturan rule dari perhitungan data training maka selanjutnya adalah melakukan uji rule menggunakan data testing sebanyak 41 data sebagai berikut: TABEL XI. UJI RULE DATA TESTING

\begin{tabular}{|c|c|c|c|c|c|c|c|c|}
\hline No & Nama & $\begin{array}{c}\text { Jawab } \\
\text { A }\end{array}$ & $\begin{array}{c}\text { Jawab } \\
\text { B } \\
\end{array}$ & $\begin{array}{c}\text { Jawab } \\
\mathrm{C} \\
\end{array}$ & $\begin{array}{c}\text { Minat } \\
\text { Asli }\end{array}$ & Rule & $\begin{array}{l}\text { Minat } \\
\text { Hasil } \\
\end{array}$ & Tepat \\
\hline 1 & Abi Saputra & 5 & 12 & 13 & Fisika & 6 & Kimia & $\begin{array}{l}\text { Tidak } \\
\text { Tepat }\end{array}$ \\
\hline 2 & Amelia M & 5 & 8 & 17 & Fisika & 4 & Fisika & Tepat \\
\hline 3 & $\begin{array}{l}\text { Annisa } \\
\text { Nuraini S }\end{array}$ & 16 & 5 & 9 & Biologi & 1 & Biologi & Tepat \\
\hline 4 & $\begin{array}{l}\text { Arya Putra } \\
\text { Fauzi }\end{array}$ & 8 & 8 & 14 & Fisika & 4 & Fisika & Tepat \\
\hline 5 & $\begin{array}{l}\text { Bima } \\
\text { Septaragi }\end{array}$ & 12 & 6 & 12 & Fisika & 5 & Fisika & Tepat \\
\hline 6 & $\begin{array}{l}\text { Elya } \\
\text { Magpiroh }\end{array}$ & 14 & 12 & 4 & Biologi & 3 & Biologi & Tepat \\
\hline 7 & $\begin{array}{l}\text { Hanum } \\
\text { Septiana }\end{array}$ & 24 & 3 & 3 & Biologi & 1 & Biologi & Tepat \\
\hline 8 & $\begin{array}{l}\text { Imas } \\
\text { Masruroh }\end{array}$ & 15 & 8 & 7 & Biologi & 1 & Biologi & Tepat \\
\hline 9 & $\begin{array}{l}\text { Keny } \\
\text { Yulianah }\end{array}$ & 21 & 3 & 6 & Biologi & 1 & Biologi & Tepat \\
\hline 10 & $\begin{array}{l}\text { Lena } \\
\text { Apriyana }\end{array}$ & 13 & 12 & 5 & Biologi & 3 & Biologi & Tepat \\
\hline 11 & $\begin{array}{l}\text { Lisa } \\
\text { Lidiana P }\end{array}$ & 11 & 8 & 11 & Fisika & 5 & Fisika & Tepat \\
\hline 12 & $\begin{array}{l}\text { Marsha } \\
\text { Salisa A }\end{array}$ & 15 & 8 & 7 & Biologi & 1 & Biologi & Tepat \\
\hline 13 & Mei Fuji R & 11 & 12 & 7 & Kimia & 3 & Biologi & $\begin{array}{l}\text { Tidak } \\
\text { Tepat }\end{array}$ \\
\hline 14 & $\begin{array}{l}\text { Mella } \\
\text { Handayani }\end{array}$ & 22 & 7 & 1 & Biologi & 1 & Biologi & Tepat \\
\hline 15 & $\begin{array}{l}\text { Muhamad } \\
\text { Gibran }\end{array}$ & 9 & 15 & 6 & Kimia & 2 & Kimia & Tepat \\
\hline 16 & Mujriatul F & 25 & 3 & 2 & Biologi & 1 & Biologi & Tepat \\
\hline 17 & $\begin{array}{ll}\text { Nabila } & \text { Sri } \\
\text { Taslim } & \end{array}$ & 30 & 0 & 0 & Biologi & 1 & Biologi & Tepat \\
\hline 18 & $\begin{array}{l}\text { Nanda } \\
\text { Angraeni }\end{array}$ & 16 & 12 & 2 & Biologi & 3 & Biologi & Tepat \\
\hline 19 & $\begin{array}{l}\text { Ninda } \\
\text { Aulia }\end{array}$ & 10 & 8 & 12 & Fisika & 4 & Fisika & Tepat \\
\hline 20 & $\begin{array}{l}\text { Nurul } \\
\text { Mufarihah }\end{array}$ & 11 & 7 & 12 & Fisika & 5 & Fisika & Tepat \\
\hline 21 & $\begin{array}{l}\text { Puput } \\
\text { Melati }\end{array}$ & 22 & 6 & 2 & Biologi & 1 & Biologi & Tepat \\
\hline 22 & $\begin{array}{l}\text { Ravina } \\
\text { Aulia }\end{array}$ & 8 & 14 & 8 & Kimia & 2 & Kimia & Tepat \\
\hline 23 & Refalzi & 9 & 9 & 12 & Fisika & 4 & Fisika & Tepat \\
\hline 24 & $\begin{array}{l}\text { Resa } \\
\text { Umami }\end{array}$ & 26 & 3 & 1 & Biologi & 1 & Biologi & Tepat \\
\hline 25 & Rizal & 8 & 7 & 15 & Fisika & 4 & Fisika & Tepat \\
\hline 26 & $\begin{array}{l}\text { Septi } \\
\text { Andriani }\end{array}$ & 12 & 10 & 8 & Biologi & 1 & Biologi & Tepat \\
\hline 27 & $\begin{array}{l}\text { Shalsabilla } \\
\text { A. C }\end{array}$ & 14 & 8 & 8 & Biologi & 1 & Biologi & Tepat \\
\hline 28 & $\begin{array}{l}\text { Siti } \\
\text { Khodijah }\end{array}$ & 0 & 0 & 30 & Fisika & 4 & Fisika & Tepat \\
\hline 29 & Suherni & 11 & 13 & 6 & Kimia & 3 & Biologi & $\begin{array}{l}\text { Tidak } \\
\text { Tepat }\end{array}$ \\
\hline 30 & Sulhah & 19 & 5 & 6 & Biologi & 1 & Biologi & Tepat \\
\hline 31 & $\begin{array}{l}\text { Surifatul } \\
\text { Naima }\end{array}$ & 10 & 10 & 10 & Fisika & 1 & Biologi & $\begin{array}{l}\text { Tidak } \\
\text { Tepat }\end{array}$ \\
\hline 32 & Sutihat & 11 & 14 & 5 & Kimia & 3 & Biologi & Tidak \\
\hline
\end{tabular}

\begin{tabular}{|c|l|c|c|c|c|c|c|c|}
\hline 33 & $\begin{array}{l}\text { Talitha } \\
\text { Fauziah }\end{array}$ & 16 & 8 & 6 & Biologi & 1 & Biologi & Tepat \\
\hline 34 & $\begin{array}{l}\text { Tasya } \\
\text { Adela T }\end{array}$ & 6 & 10 & 14 & Fisika & 4 & Fisika & Tepat \\
\hline 35 & $\begin{array}{l}\text { Teguh } \\
\text { Rizki }\end{array}$ & 11 & 11 & 8 & Kimia & 3 & Biologi & $\begin{array}{l}\text { Tidak } \\
\text { Tepat }\end{array}$ \\
\hline 36 & $\begin{array}{l}\text { Tsabita } \\
\text { Dayana }\end{array}$ & 10 & 17 & 3 & Kimia & 6 & Kimia & Tepat \\
\hline 37 & $\begin{array}{l}\text { Tusi } \\
\text { Rahmawati }\end{array}$ & 7 & 12 & 11 & Kimia & 2 & Kimia & Tepat \\
\hline 38 & $\begin{array}{l}\text { Utari Ayu } \\
\text { W }\end{array}$ & 6 & 21 & 3 & Kimia & 2 & Kimia & Tepat \\
\hline 39 & $\begin{array}{l}\text { Widya } \\
\text { Ningsih }\end{array}$ & 30 & 0 & 0 & Biologi & 1 & Biologi & Tepat \\
\hline 40 & $\begin{array}{l}\text { Yulia } \\
\text { Salsabila }\end{array}$ & 11 & 13 & 6 & Kimia & 3 & Biologi & $\begin{array}{l}\text { Tidak } \\
\text { Tepat }\end{array}$ \\
\hline 41 & $\begin{array}{l}\text { Zamelia } \\
\text { Maulida }\end{array}$ & 18 & 5 & 7 & Biologi & 1 & Biologi & Tepat \\
\hline
\end{tabular}

\section{HASIL DAN PEMBAHASAN}

Pada penelitian ini untuk menghitung kinerja dari klasifikasi ini menggunakan metode confusion matrix dari hasil uji rule data testing maka diperoleh nilai akurasi yaitu 82,82\%.

Setelah sistem selesai dirancang dan dibangun, evaluasi sistem dilakukan menggunakan kuesioner. Kuesioner diberikan kepada 10 responden di SMA Negeri 1 Anyer yang berbeda. Berikut tabel hasil kuesioner.

\section{TABEL XII. REKAPITULASI HASIL KUESIONER}

\begin{tabular}{|c|l|c|c|c|c|c|}
\hline No & \multicolumn{1}{|c|}{ Nama Responden } & P1 & P2 & P3 & P4 & P5 \\
\hline 1 & Mei Fuji Rahayu & 4 & 4 & 5 & 5 & 4 \\
\hline 2 & Suherni & 5 & 4 & 5 & 4 & 4 \\
\hline 3 & Ninda Aulia & 4 & 5 & 5 & 5 & 4 \\
\hline 4 & Rizal & 5 & 5 & 4 & 5 & 5 \\
\hline 5 & Annisa Nuraini S & 4 & 4 & 4 & 4 & 4 \\
\hline 6 & Arya Putra Fauzi & 5 & 4 & 4 & 4 & 4 \\
\hline 7 & Bima Sepatargi & 4 & 4 & 4 & 5 & 5 \\
\hline 8 & Faizal Bagus Z & 5 & 4 & 4 & 5 & 5 \\
\hline 9 & Septi Andriani & 4 & 5 & 5 & 4 & 5 \\
\hline 10 & Valentina & 5 & 4 & 4 & 5 & 4 \\
\hline
\end{tabular}

Berdasarkan rekapitulasi hasil kuesioner pada Tabel XII, maka selanjutnya dilakukan perhitungan hasil skor dengan menggunakan Skala Likert. Pengujian menggunakan skala likert merupakan skala yang paling banyak digunakan dalam riset berupa survey, dan pengujian penelitian deskriptif. Pada pengujian skala likert responden diminta untuk menentukan tingkat persetujuan mereka terhadap suatu pertanyaan dengan memilih salah satu pilihan yang telah tersedia [10].

Hasil skor kemudian dihitung persentase kelayakannya. Berikut merupakan hasil dari perhitungan persentase kelayakan setiap variabel yang disajikan dalam Tabel XIII.

TABEL XIII. HASIL PERHITUNGAN KUESIONER

\begin{tabular}{|c|c|c|c|c|c|c|c|c|}
\hline \multirow[b]{2}{*}{ No } & \multirow[b]{2}{*}{ Pernyataan } & \multicolumn{5}{|c|}{ Keterangan } & \multirow{2}{*}{$\begin{array}{l}\text { Total } \\
\text { Skor }\end{array}$} & \multirow{2}{*}{$\begin{array}{l}\text { Interpr } \\
\text { etasi } \\
\text { Index }\end{array}$} \\
\hline & & STS & TS & KS & S & SS & & \\
\hline 1 & $\begin{array}{l}\text { Saudara/i membutuhkan } \\
\text { adanya aplikasi } \\
\text { klasifikasi kelas lintas } \\
\text { minat }\end{array}$ & 0 & 0 & 0 & 25 & 20 & 45 & $90 \%$ \\
\hline 2 & $\begin{array}{l}\text { Saudara/i memerlukan } \\
\text { informasi tentang mata } \\
\text { pelajaran lintas minat }\end{array}$ & 0 & 0 & 0 & 15 & 28 & 43 & $94 \%$ \\
\hline 3 & $\begin{array}{lr}\text { Saudara/i } & \text { terbantu } \\
\text { dengan adanya } & \text { aplikasi } \\
\text { lintas minat } & \\
\end{array}$ & 0 & 0 & 0 & 20 & 24 & 44 & $88 \%$ \\
\hline 4 & $\begin{array}{l}\text { Aplikasi lintas minat ini } \\
\text { mudah digunakan oleh } \\
\text { saudara/i }\end{array}$ & 0 & 0 & 0 & 30 & 16 & 46 & $92 \%$ \\
\hline
\end{tabular}




\begin{tabular}{|c|c|c|c|c|c|c|c|c|}
\hline 5 & $\begin{array}{l}\text { Saudara/i merasa puas } \\
\text { ketika mengetahui hasil } \\
\text { kelas lintas minat sesuai } \\
\text { dengan anda }\end{array}$ & 0 & 0 & 0 & 20 & 24 & 44 & $88 \%$ \\
\hline
\end{tabular}

\section{KESIMPULAN} berikut :

Kesimpulan yang didapat pada penelitian ini adalah sebagai

1) Aplikasi sistem klasifikasi ini dapat memberikan hasil kelas lintas minat melalui atribut sebanyak 30 butir untuk setiap alternatifnya. Atribut yang digunakan diperoleh dari kriteria pada setiap mata pelajaran lintas minat.

2) Pada perhitungan ini terdapat 2 tahapan yaitu tahapan perhitungan data training dimana diambil sebanyak 103 data siswa untuk diolah. Dan tahapan pengujian data testing sebanyak 41 data siswa, pada tahapan ini didapat nilai akurasi sebesar $82,82 \%$.

3) Model klasifikasi lintas minat siswa ini dapat digunakan sebagai alternatif referensi bagi guru BK untuk dapat mengelompokkan siswa berdasarkan minat dan bakat pada saat pohon keputusan ini terbentuk.

\section{UCAPAN TERIMA KASIH}

Saya mengucapkan terima kasih kepada pihak-pihak yang telah membantu dalam penerbitan paper ini.

\section{REFERENSI}

[1] Permendikbud, Pedoman Peminatan Peserta Didik. Jakarta : Permendikbud, 2014.

[2] P. Innike Marbitha, "Identifikasi Antusiasme Dan Hasil Belajar Siswa Kelas X IPS Pada Mata Pelajaran Biologi Program Peminatan Di SMA Negeri Colomadu Tahun Ajaran 2015/2016". Skripsi pada Universitas Muhammadiyah Surakarta. Tidak Diterbitkan, 2016.

[3] P. Eko, Data Mining Mengolah Data Menjadi Informasi Menggunakan Matlab. Yogyakarta: Andi, 2014.

[4] Whitten, Jeffrey L. dan Bentley, Lonnie D. (2010). Systems Analysis And Design Methods. New York: McGraw-Hill/Irwin.

[5] Widodo, Prabowo P. dkk (2011). Pemodelan Sistem Berorientasi Obyek Dengan UML. Graha ilmu: Yogyakarta

[6] Sugiyono, Metode Penelitian Kuantitatif Kualitatif dan R\&D. Bandung: Alfabeta, 2009.

[7] Turban, E. dkk, Decision Support Systems and Intelligent Systems. Yogyakarta: Andi, 2005.

[8] Munandar, Tb Ai, Modul Perkuliahan Data mining Edisi Revisi 2. Serang: Universitas Serang Raya, 2018.

[9] Joiţa. D, Unsupervised static discretization methods in data mining. Bucharest, Romania: Titu Maiorescu University, 2010.

[10] Jogiyanto, Metodologi Penelitian Sistem Informasi. Yogyakarta: Andi, 2008. 